\title{
Perlecan is a Multifunctional Modulator in Development and Diseases
}

\author{
発生や疾患を調整するパールカンの多様な機能
}

\author{
Arikawa-Hirasawa, Eri ${ }^{1,2}$ \\ ${ }^{1}$ Research Institute for Diseases of Old Age and ${ }^{2}$ Department of Neurology, Juntendo University School of Medicine, \\ 2-1-1 Hongo, Bunkyo-ku, Tokyo 113-8421, Japan \\ FAX: 81-3-3814-3016, E-mail: ehirasaw@ @ed.juntendo.ac.jp \\ Key Words: perlecan, heparan sulfate proteoglycan, neuromuscular junction, mouse model, chondrodysplasia
}

\begin{abstract}
Perlecan has multiple functions in cell growth and differentiation and tissue homeostasis. Recent studies with mutant mice and human genetic disorders have shed light into the in vivo functions of perlecan. Complete deficiency of perlecan results in embryonic and perinatal lethality with severe defects in cartilage, cephalic development and cardiovascular systems. In adult tissues, perlecan is essential for high density clustering of acetylcholinesterase (AChE) at the neuromuscular junction (NMJ) and partially functional mutations of perlecan result in myotonia and milder chondrodysplasia. Deletion of a short coding sequence including the HS attachment sites of the N-terminus of perlecan in mice revealed that the HS chains are not essential for development but play a role in supporting the integrity of the lens capsule, in promoting angiogenesis and tumor growth, and filtration in the kidney. In vitro studies indicate that many extracellular molecules and cell surface receptors interact with the HS chains and core protein of perlecan. Perlecan may work as a modulator for growth factor signaling and a ligand reservoir.
\end{abstract}

\section{A. Introduction}

A specific class of proteoglycans, known as heparan sulfate proteoglycans (HSPGs), has been paid attention in many different fields as a key regulatory molecule for crucial biological processes in embryonic development, inflammation, wound repair, and cancer. There are a number of genes for the core proteins of heparan sulfate proteoglycans, including four members of the syndecan family, the glypican family, perlecan, agrin, and collagen XVIII (1-4). Perlecan is expressed in all basement membranes and other matrices such as cartilage (5). The large protein core $(400 \mathrm{kDa})$ of perlecan consists of five distinctive functional domains. The protein core is substituted with 2-3 heparan sulfate (HS) chains at the $\mathrm{N}$-terminal domain I and one or two HS/chondroitin sulfate (CS) chains at the C-terminal domain $\mathrm{V}(6,7)$. In certain

\section{要 約}

パールカンは細胞の成長や分化、組織機能に多様な働きを

している。近年、遺伝子改変マウスやヒト遺伝性疾患の研究 を通じてパールカンの生体における機能が少しずつ解明され ようとしている。パールカンが完全に欠損すると、軟骨、頭部、 心血管系の異常を伴い、一部は胎生期、その他は周産期致死 性を示す。また、パールカンは神経筋接合部にアセチルコリ ンエステレースを高濃度に局在させるのに必須であり、バー ルカンの機能部分欠損はミオトニアと骨格異常を呈する軽症 型の遺伝性疾患の原因となる。パールカンの $\mathrm{N}$ - 端に位置する ヘパラン硫酸鎖 $(\mathrm{HS}$ 鎖) 結合部位を欠損させた遺伝子改変マ ウスの解析からは、HS 鎖が眼球レンズ包の機能保全、血管新 生や腫瘍の成長、腎での滤過機構に重要であることが解った。 このように、マウスモデルの解析により、バールカンのコア タンパク質や HS 鎖が他の細胞外マトリックス分子や細胞表面 受容体と相互作用することが解ってきた。パールカンは成長 因子を捕らえて、その機能を調整しているようである。

\section{A. 序 文}

ヘパラン硫酸プロテオグリカンは発生、炎症、創傷治癒、 腫瘍形成における重要な生物学的活性を制御する分子群とし て各分野から注目されている。ヘパラン硫酸プロテオグリカ ンのコアタンパク質をコードする遺伝子は多く、代表的なも のにシンデカンファミリー、グリピカンファミリー、パール カン、アグリン及びXVIII 型コラーゲンなどがある $(1-4):$ バー ルカンは全ての基底膜と軟骨などの、マトリックスに発現す る。パールカンの巨大なコアタンパク質は 5 つの機能ドメイ ンに分かれており、N 端のドメイン Iには 2 - 3 本のへパラン 硫酸鎖が、C 端のドメインVには 1 ～2 本のヘパラン硫酸鎖 もしくはコンドロイチン硫酸鎖が付く $(5-7)$ 。組織や発生の時 期の違いによりこれらの GAG 鎖はコンドロイチン硫酸鎖、デ 
tissues or developmental stages, these GAG attachment sites could be substituted with other glycosaminoglycan chains, such as CS, dermatan sulfate (DS), HS/CS, CS/DS, or secreted as GAG-free glycoprotein (see the review of Jiang et al., 2003(8)). These variations of GAG chains may imply diverse roles of perlecan in tissue development and functions. Perlecan binds extracellular matrix molecules, growth factors, and cell surface receptors. Perlecan has been implicated in a number of biological activities in human diseases. Recently, studies with gene knockout mice have been created $(9,10)$ and two different human genetic disorders have been identified as having perlecan gene mutations $(11,12)$. In this report, I will review in vivo functions of perlecan in development and diseases.

\section{B. Biology of Perlecan Core and GAG Chains \\ B-1. Structure and Function of Perlecan Core}

The amino acid sequence of mouse perlecan from cDNA cloning $(6,7)$ indicates that the protein core is $369 \mathrm{kDa}$ in size and consists of five distinct domains (Fig. 1). Domain I contains an SEA (Spperm protein, Enterokinase, Agrin) module and three Ser-Gly-Asp peptide sequences, in which the serine residue is a site for heparan sulfate attachment (13). Domain II is similar to the cholesterol-binding region of the LDL receptor and domain III has homology with the short arm of laminin $\alpha$ chains. Domain IV is the largest domain and consists of 14 repeats of IgG-like motifs similar to those found in the neural cell adhesion molecule (N-CAM). Domain V has three globular subdomains, similar to the LG subdomain of

ルマタン硫酸鎖 (DS)、あるいは 2 種類の GAG 鎖のハイブリッ ド鎖に置き換わったり、GAGを付けない状態で分泌されたり する可能性があり (Jiang らの総説参照 (8) 2003)、これらの糖 鎖の多様性がパールカンの発生や組織機能における多㥞性を 生み出しているのかもしれない。パールカンは細胞外分子、 成長因子、細胞表面受容体に結合し、ヒト疾患に扔いても多 くの事象に関わっている。近年、ノックアウトマウスが作製 され $(9 、 10) 、 さ ら に 2$ 種類のヒト遺伝性疾患がパールカンの 遺伝子異常に起因することが解った $(11 、 12)$ 。本稿ではこれら の結果をふまえ、パールカンの生体における機能について概 説する。

B. パールカンのコアタンパク質と GAG 鎖の機能

\section{B-1.コアタンパク質の構造}

パールカンの cDNA から得られたアミノ酸配列からハー ルカンのコアタンパク質は $369 \mathrm{kD}$ に及ぶ巨大なもので、5つ のドメインからなる構造を持つことが解った $(6.7)$ 。ドメイ ンIは、SEA (Sperm protein, Enterokinase, Agrin) モジュール๖ SerGlyAsp のペプチドシークエンスを含み、この Ser 残基がへ パラン硫酸鎖結合部位である (13)。ドメイン II は、LDL受容 体のコレステロール結合部位に、ドメイン III はラミニン $\alpha$ 鎖 の短腕に相同性を持つ。ドメイン IVは最も大きいドメインで
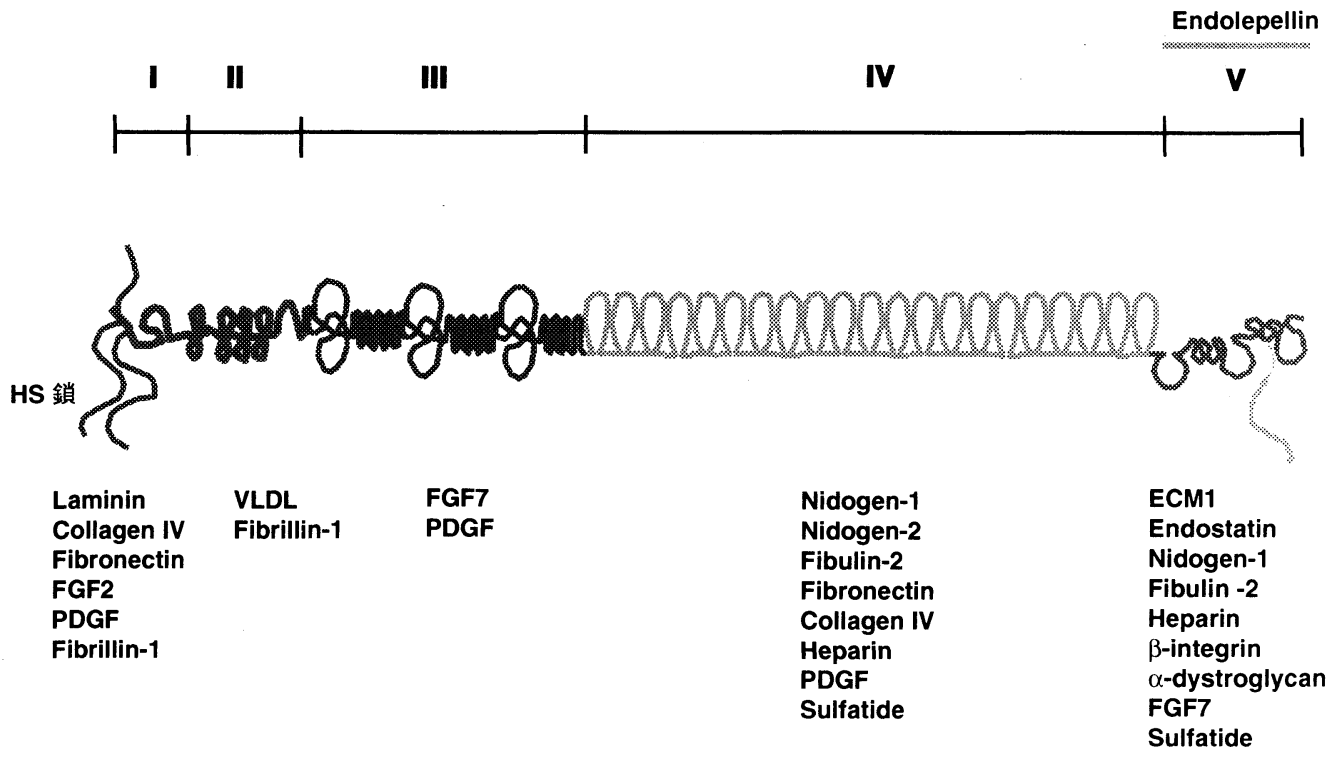

Fig. 1. Structure of perlecan and binding molecules. GAG chains are shown in red and blue in domains I and $\mathrm{V}$, respectively. Domain I contains GAG attachment sites and an SEA module. Domain II has homology to low-density lipoprotein (LDL). Domain III is homologous to the short arm of laminin $\alpha$ chains. Domain IV consists of lg-like repeats. similar to N-CAM. Domain V contains three globular domains homologous to C-terminal laminin $\alpha$ chain globular subdomains, which are interrupted by four EGF-like modules. Molecules bound to perlecan domains are shown under the schematic structure of perlecan. 
laminin $\alpha$ chains, with interruptions by four EGF-like motifs, and can be substituted with HS and/or CS chains (14). These domains bind extracellular matrices (15-21), growth factors, and cell surface receptors (17).

The structures of mouse and human perlecan are very similar except that domain IV of mouse perlecan contains 7 more repeats of the IgG-like motifs, which increases the core protein to $466 \mathrm{kDa}(18)$. The homologue of perlecan is also present in the basement membranes of C. elegans (20, $21)$ and Drosophila $(15,22)$. Mutations in the alternatively spliced perlecan gene in $C$. elegans produce defective muscle development and cause paralysis (23). Perlecan is implicated in supporting basement membrane structure, since it interacts with basement membrane components. The HS chains interact with collagen IV and laminins (reviewed in Bernfield et al., 1999). The core protein also binds collagen IV, nidogen/entactin-1 and -2, and fibulin-2 (24, 25) (Fig. 1). Perlecan can self-aggregate into dimers and multimers via domain $\mathrm{V}$ in vitro. Domain $\mathrm{V}$ interacts with cell surface receptors such as $\alpha 1$ integrin and $\alpha$-dystroglycan $(14,26)$, suggesting possible competitive action with laminin or agrin. Perlecan $\mathrm{s}$ ability to interact with many proteins and receptors suggests that perlecan provides structural support for the basement membrane and bridges matrix and cell interactions for the stable formation of tissue architecture.

\section{B-2. GAG Chains of Perlecan}

As described in the introduction, GAG chains of perlecan have some variation and modification. The size of the GAG chains also varies according to tissue and cell type $(27,28)$. Biological activity of perlecan may be varied due to different levels of modifications of these sugar chains. Genetically modified mice, in which the HS attachment sites at the $\mathrm{N}$ terminus of perlecan are deleted, survive embryonic development and are viable and fertile but develop small eyes (29). However, mutant mice exhibit significantly delayed wound healing, defective angiogenesis and retarded tumor growth (30). Although these results suggest that the HS chains of perlecan positively regulate angiogenesis in vivo, gene knockout of the whole perlecan molecule may result in different phenotypes. Additionally, the mutant mice without perlecan HS chain exhibited remarkable proteinuria when BSA was administered intraperitoneally, suggesting that HS chains of perlecan play an important role in glomerular filtration, especially for a large amount of proteins (31).

\section{Perlecan in Embryogenesis}

Expression of perlecan is detectable in a very early stage of embryogenesis. Perlecan is first expressed on the external trophectodermal cell surfaces of mouse blastocysts and its expression level increases in the peri-implantation period (32). Perlecan expression appears early in tissues
あり、N-CAMのイムノグロブリン様の繰り返し構造を持つ。 ドメイン V は、EGF様モチーフをはさんで、ラミニン $\alpha$ 鎖の LG サブドメインを 3 つ持つ。このドメイン V には、へバラン 硫酸鎖もしくはコンドロイチン硫酸鎖が付く(14-16)。これら のドメインは細胞外マトリックスに結合する(15-21)。 ママウス とヒトのパールカンは構造が非常に似ているが、マウスのド メインIVのイムノグロブリン様の繰り返し構造が7つ長いた め、そのコアタンパク質は $466 \mathrm{kDa}$ と大きくなる $(18)$ ○パール カンの相同体は、線虫 $(20 、 21)$ やショウジョウバエ $(15,22) に$ も存在し、線虫のパールカンのスプライシング変異は筋発生 の異常による運動麻痺を引き起こすことが知られている (2.3) パールカンは基底膜の構成成分と相互作用し、基底膜の構造 に重要と考えられる。ヘバン硫酸鎖はIV 型コラーゲン、各 種ラミニンと結合するが、コアタンパク質も IV 型コラーゲン、 ナイドジェン $1 、 2 、$ 抢よびフィブリン 2 等と結合する $(1,24 、 25) 。$ パールカンは、ドメイン Vの自己会合で 2 量体や多量体を形 成することもあるとされる。このドメイン $\mathrm{V}$ は $\beta 1$ インテグリ ンや $\alpha$ ジストログリカン等の細胞表面受容体との結合能を持 ち (14、26)、ラミニンやアグリン等と競合してはたらく可能性 もある。このようなパールカンの多様な結合能が基底膜を構 造的に支持し、細胞とマトリックスを漸結させ、組織形成を 安定させていると考えられる。

\section{B-2. パールカンの GAG 鎖}

組織や細胞種の違いにより $\mathrm{GAG}$ 鎖の長さにも多様性があ ると考えられる。

先に序文で述べたようにパールカンに付く GAG 鎖の種類 には多様性があるが、組織や細胞の種類によってその長さに も多様性がある (27、28)。パールカンの生物学的活性の多様性 はこのような GAG 鎖の可変性によっているかもしれない N 端にあるへパラン硫酸結合部位の小欠損を起こす遺伝子改変 マウスは生存し、交配可能であることがわかった。このマウ スは眼球が小さい以外は一見正常であるが、創傷治癒、血管 新生が遅延し、腫瘍成長が遅いことが報告された $(29 、 30)$ ： し かし、ヘパラン硫酸鎖欠損マウスの解析結果において、ハー ルカンのヘパラン硫酸鎖が血管新生を促焦していても、バー ルカン全体を欠損させた場合にはまた違った結果が得られる 可能性もある。さらに、最近では、パールカンのヘバラン硫 酸鎖が欠損したマウスにBSAの腹腔内投与を行った場会、著 明なタンパク尿を引き起こすことが分かり、パールカンのへ パラン硫酸鎖が、分子量が大きな分子の系球体濾渦に重要な 役割を担っていることが示された (31)。

\section{C. 発生におけるパールカンの役割}

パールカンは胚発生の非常に早期から発現するっパールカ ンはマウス胚盤胞の栄養外胚葉に最初に発現し、その㣪着床 前後にその発現量が急速に増加する(32)。また、組織形成に 
for vasculogenesis, including heart, pericardium, and major blood vessels (33). Perlecan is also expressed in developing cartilage, especially in the hypertrophic zone. During later stages of development, perlecan mRNA levels progressively increase, and its expression correlates with the onset of tissue differentiation of various parenchymal organs, including the developing kidneys, lungs, liver, spleen, and gastrointestinal tract. Despite ubiquitous expression in all basement membranes from very early embryonic stages, deficiency of perlecan does not affect implantation or early embryogenesis. Unexpectedly, perlecan-null mutation in mice causes perinatal lethal chondrodysplasia. Some of the perlecan-null mice die around embryonic day 10.5 with defects in cephalic development and cardiomyocyte basement membranes $(9,10)$. Perlecan-null mice, which survive beyond this stage develop skeletal dysplasia characterized by defective cartilage, short limbs and craniofacial abnormalities, and they die shortly after birth with respiratory failure (9).

\section{Role of Perlecan in Cartilage Formation}

Perlecan originally identified as a basement membrane component. It also expresses in cartilage throughout the entire developmental stages (5). Although perlecan is abundant in cartilage, the role of perlecan in cartilage development was not clear until perlecan mutant mice were created. Human disease caused by null mutations of perlecan has been identified and its phenotypes are very similar to perlecan-null mice(9).

\section{D-1. Lethal Chondrodysplasia Phenotype of Perlecan-Null Mice}

Cartilage of perlecan-null mice reveals a disorganized growth plate with reduced chondrocyte proliferation and differentiation and defects in endochondral ossification (9). The columnar structure of hypertrophic chondrocytes in the growth plate is severely disturbed in mutant mice. The vertebral bodies of mutant mice are reduced in height but their width is increased with multiple ossification centers at the periphery. The abnormalities of cartilage are not clear until about embryonic day 14.5, when endochondral ossification begins, and after this stage, abnormalities become progressively severe. Cartilage matrix in perlecan-null mice contains reduced and disorganized collagen fibrils and glycosaminoglycans in electron microscopy, suggesting that perlecan plays an important role in cartilage matrix formation. Perlecan-null growth plate also shows reduced chondrocyte proliferation and little expression of Indian hedgehog, a marker for prehypertrophic chondrocytes. Since FGF/ FGFR3c signaling regulates chondrocyte differentiation and proliferation in the growth plate, these results may suggest that perlecan modulates FGF signaling in cartilage development. The phenotype of the growth plate of perlecan-null mice is similar to that caused by constitutively activating mutations
関与しており、心、血管の形成に伴い発現が明暸化してくる。 また、軟骨形成に際してもパールカンの発現が確認され、特 に肥大軟骨層で強い発現を見る。E13.5以降の後期胚発生ににお いて、腎、肺、肝等の実質臟器の発達に伴いパールカンの発 現量は徐々に増加していく(33)。このような発生初期からの ユビキタスな発現パターンにもかかわらず、パールカンの欠 損は着床や肧発生に大きな影響を与えず、軟骨異常による周 産期致死という意外な結果を示した $(9 、 10)$ 。パールカン久損 マウスの一部は E10.5 前後に心血管系や頭部の発生異常により 死亡したが、この時期を乗り越えた胚は軟骨異常による短い 四肢や頭蓋顔面の形成異常を特徵とする骨格異常を伴い出生 後まもなく呼吸不全で死亡した $(9)$ 。

\section{D. 軟骨形成におけるパールカンの機能}

パールカンは、最初基底膜の構成成分として同定された が、後に軟骨発生において発現し続けることが解った(5)。し かし、パールカンの軟骨発生に扔ける機能はそのノックアウ トマウスが作製、解析されるまで良く解っていなかったささ らにヒトでのパールカン欠損疾患もノックアウトマウスの症 状と非常によく似ていたことから、同定することができた (9)。

\section{D-1. パールカン欠損マウスの致死性軟骨異形成症}

パールカンノックアウトマウスは軟骨細胞の増殖分化に 異常を来し、内軟骨性化骨が障害される。成長板の肥大軟骨 のカラム構造がほとんど形成されなかった (9)。長管骨以外で も、椎体において太くて短いという特徽が観察され、やはり 内軟骨性骨化の異常によると考えられる不規則な骨化中心を 骨周辺部に多数認めた。この軟骨の異常は骨化が始まるE14.5 までははっきりしないが、その後次第に明確になっていく パールカンが欠損した軟骨では、電顕で観祭されるマトリッ クス中のコラーゲンフィブリルとグライコサミノグライカン 量が減少し、コラーゲン線維構築が乱れている。バールカン が欠損すると成長板の前肥大軟骨層での軟骨細胞の増殖が低 下し、通常前肥大軟骨層で特異的に発現されるインデアンへ ジホグ (Ihh) が消失する。成長軟骨においては、FGF/FGF 受容 体 $3 \mathrm{c}$ が軟骨の増殖分化を制御しているので FGFの共受容体で あるパールカンがこれらのシグナルを修飾している可能性が 示唆される結果である。パールカン欠損マウスの成長板の異 常はヒトに扔ける FGF 受容体 3 の活性型変異疾患の異常と類 似し (34-36)、FGF 受容体3 欠損マウスにおいて長管骨が伸長 する異常とで反対の長管骨の短縮を引き起こす (37-39)。この 
of FGFR3 in humans (34-36) and is opposite to that of Fgfr3-null mice, which shows the extended growth plate (37 -39). These results suggest that perlecan may be a negative regulator of FGFR3 signaling for cartilage development. Perlecan may act as ligands/growth factors reservoir in the matrix and inhibit signaling in cartilage development.

\section{D-2. Functional-Null Mutations in Humans with Dyssegmental Dysplasia, Silverman-Handmaker Type}

Similarities of growth plate histology and X-ray findings for skeletal abnormalities of perlecan-null mice led to the identification of a human disorder called Dyssegmental dysplasia, Silverman-Handmaker type (DDSH) (40). DDSH is a rare lethal autosomal recessive skeletal dysplasia characterized by anisospondyly and micromelia (41). The endochondral growth plate of DDSH patients is short and contains large and unfused calcospherites in the hypertrophic zone similar to that of the perlecan mutant mice. Immunostaining with an antibody to the perlecan core protein showed strong staining of the pericellular cartilage matrix in normal controls. However, there was little staining in the DDSH cartilage matrix, but there was significant staining of inclusion bodies within the cells. Similar immunostaining results were observed with cultured fibroblasts from DDSH patients. Biochemical analysis revealed that normal sized perlecan core protein was not detected in the condition media from DDSH fibroblasts, but several smaller sized proteins were detected in the cell lysates. Mutations in three DDSH patients are predicted to produce premature termination codons (40). Immunostaining reveals that truncated proteins are synthesized but not secreted. Thus, DDSH is caused by functional null mutations of the perlecan gene. Taken together with similar phenotypes of knockout mice, perlecan is indispensable for cartilage development.

\section{D-3. Partially Functional Mutations in Humans with Schwartz-Jampel Syndrome}

Phenotypic differences in DDSH and SchwartzJampel syndrome (SJS) appear to reflect differences in complete deficiency of perlecan and partially functional truncated perlecan. Unlike DDSH, SJS mutations result in different, abnormal forms of the perlecan molecule in reduced levels that are secreted into the extracellular matrix and are partially functional. Spanger $e t a l$. reported that other skeletal dysplasias previously identified as chondrodysplasias, such as kyphomelic chondrodysplasia, micromelic chondrodysplasia, and Burton's disease, could be reclassified based on a clinical examination as SJS (42). Mutation analyses of the perlecan gene will be required for diagnoses of chondrodysplasia and myotonic myopathy. These mutation searches may reveal a wider spectrum of the SJS phenotype in the near future.

\section{D-4. Perlecan in Osteoarthritis}

Cartilage samples from patients suffering from late-
ことは、パールカンがFGF受容体 3 のシグナルを負に制御し ている可能性を示している。パールカンは成長因子などのリ ガンドを軟骨マトリックス中に貯留することにより、FGF シ グナルに抑制的に働いているかもしれない。

D-2. Silverman-Handmaker 型 dyssegmental dysplasia はパー ルカンの機能欠損変異により発症する疾患である

我々は、パールカン欠損マウスの成長板病理所見と骨レ ントゲン写真所見の類似性からパールカン欠損により発症 するヒト遺伝性疾患の同定に至った (40)。これはSilvermanHandmaker 型 dyssegmental dysplasia (DDSH) と称されるまれな 疾患で、遺伝形式は常染色体劣性遺伝型である (41)。DDSH 患者の成長板は短く、肥大軟骨層に、特徵的な粗大石兏小球 (calcospherites) を認め、パールカン欠損マウスとよく似た特 徵を示した。パールカンコアタンパク質に対する抗体による 免疫染色では、パールカンは軟骨マトリックス、特に細胞周 囲のマトリックスに強く存在するが、DDSH患者ではそのよ うな染色はほとんど認められなかった。同様にDDSH 患者培 養線維芽細胞を用いた免疫染色でもパールカンはマトリック スで欠損していた。生化学的な検討でも、DDSH 線維芽細胞 の培養上清中に正常な大きさのパールカンコアは検出されず、 小さいサイズのフラグメントが細胞分画で確認された (40) DDSH 患者で検出された遺伝子変異は premature termination を 起こすことが予測され、免疫組織染色の結果から予測された 短い夕ンパク質は合成されても細胞外に分泌されていないこ とが明らかとなった。このようにして、DDSHはバールカン 遺伝子の機能完全欠損型変異に起因することが分かった。こ れら、ノックアウトマウスとヒト遺伝性疾患の類似性がバー ルカンの軟骨発生における重要性を示したわけである

D-3. Schwartz-Jampel 症候群におけるパールカンの機能部分 欠損

Schwartz-Jampel 症候群 (SJS) におけるパールカンの遺伝 子変異は、最初ポジショナルプローニングと連鎖解析によっ て同定された $(11 、 12)$ 。SJS は常染色体劣性遺伝形式をとるま れな疾患であり、ミオトニアと軟骨異形成が合併する、しか しながら DDSH と異なり、SJS 患者は生存することができる。 この違いはパールカンの機能欠損が完全欠損か、部分久損か によると考えられる。SJSの変異によるパールカンタンバク 質は、質的、量的に異常であるが、細胞の外に分泌され、マ トリックスとして、部分的に機能する。Sprangerらは、過去 に軟骨異形成として同定された kyphomelic chondrodysplasia、 micromelic chondrodysplasia、Burton 病は、今後さらに検討が すすめば、SJS として分類される可能性があることをしめした (42)。今後、ミオトニアや軟骨異常あを伴う症例に対して、バー ルカン遺伝子の变異を検討することによりSJS の疾患スベク トラムに拡がりが期待される。

D-4. 関節症におけるパールカン

進行期の関節症軟骨において関節变性の主要病変部に㧍 
stage osteoarthritis reveal increased levels of perlecan in the area adjacent to the main osteoarthritis region (43). The elongated secretory type 2 cells in the area adjacent to the defective region, which were responsible for a regenerating attempt in diseased cartilage tissue, produce a large amount of perlecan. This induction of perlecan might be due to cellular attempt to stabilize the extracellular matrix. Furthermore, these type 2 cells deposit perlecan in the pericellular matrix, which may also contribute to increasing stabilization between chondrocytes and the matrix.

\section{E. Role of Perlecan in the Neuromuscular Junction}

Perlecan is present in muscle basement membranes and its expression is particularly enriched at the neuromuscular junction (NMJ) (44). The NMJ is a highly specialized structure, in which unique molecules (45), such as acetylcholinesterase (AChE), acetylcholine receptors (AChR), agrin, dystroglycans, rapsyn, and utrophin are clustered (Fig. 1). In skeletal muscles, acetylcholine (ACh) acts as a neurotransmitter. ACh binds AChR on the muscle cell surface, activates $\mathrm{Na}$ channels, and induces muscle contraction. $\mathrm{AChE}$ rapidly inactivates this process for muscle relaxation and recycling of ACh. The collagen-tail form (ColQ) of AChE is preferentially expressed in innervated regions of muscles and is shown to bind perlecan in vitro $(46,47)$. In the perlecan knockout mice, muscle development and differentiation appear to be normal, and the nerve terminals are normally formed at birth (44). Most clustering molecules are present at the NMJ of the mutant mouse muscles. However, AChE is absent at the newborn NMJ, although AChE protein is synthesized normally (44). Thus, perlecan is essential for high-density localization of AChE at the NMJ. Continuous activation of the muscle in SJS patients is likely to be caused by perlecan deficiency in NMJ.

\section{F. Perlecan and Lipoprotein in Diabetes and Atherosclerosis}

HSPGs have been implicated in the uptake and removal of atherogenic lipoproteins. Domain III of perlecan shares homology with the binding domain of LDL receptor and perlecan was demonstrated as an independent slow uptake kinetics receptor for LDL (48). Loss of perlecan in diabetic mice was also demonstrated to be responsible for delayed lipoprotein clearance, and hypercholesterolemia and hypertriglyceridemia $(49,50,51)$. Perlecan is detected in the atherosclerotic intimal lesions of apoE-null and LDLR-null mice (52) and may contribute to the retention of lipoproteins at the earliest stage of atherosclerosis. Perlecan is associated with advanced lesions of hypercholesterolemic nonhuman primates (53). Atherosclerosis was studied in heterozygous perlecan-null mice by crossing to apoE and LDL receptor knockout backgrounds. At 12 weeks, chow-fed apoE-null
いてパールカンが増加していることが報告されている(4.3) 病 変部には細長い形の分泌型の 2 型軟骨細胞があり、この練胞 の存在は病変部軟骨の再生機構と考えられる。この細胞がバー ルカンを大量に産生し、軟骨細胞が細胞外マトリックスを安 定させようとしているのかもしれない。さらに、この2 型紐 胞表面領域にはパールカンが多く沈着しており、軟骨細胞上 軟骨マトリックスの連結を強めているようである。

\section{E. 神経筋接合部におけるパールカンの機能}

パールカンは筋基底膜に存在するが、特に神経筋接合部 (NMJ) に多く存在する (44)。NMJ は特殊に分化した基底膜構

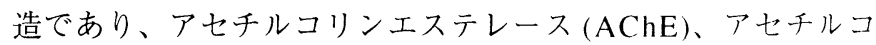
リン受容体 (AChR)、アグリン、ジストログリカン、ラフシン、 ユートロフィン等の分子が特異的に集束している (45) 骨格 筋において、アセチルコリン $(\mathrm{ACh})$ は伝撻物質として筋表面 の受容体 $(\mathrm{AChR})$ に結合し、Naチャネルを活性化し、筋を興 奮、収縮させる。 $\mathrm{ACh}$ はすみやかに分解され、筋の興奮は解 除され、AChは再利用される。AChEのコラーゲン様尾部ド メインは神経支配を受けた部分の筋細胞において強く発現し、 パールカンと結合する $(46 、 47)$ 。出生に至ったパールカン完全 欠損マウスでは、筋の発生、分化、神経支配はほぼ正常に観 察された (44)。また、ほとんどの NMJ 集合分子は AChR と供 に存在するが、AChE は生化学的に筋で存在するにも関わらず、 NMJ に局在しないことが分かった (44)。このことからハール カンがAChE を NMJに濃縮してして局在させることに必須で あることが解った。SJSに扔ける筋の持続収縮 (ミオトニア) はNMJ でのパールカンの欠損と関連していると思われる

\section{F. 糖尿病、動脈硬化の病態におけるパールカンとリポタンパ ク質の関与}

HSPG は動脈硬化誘発性リポタンパク質の取り迄みや排除 に関与していると考えられている。パールカンのドメイン III は LDL 受容体の結合部位と相同性があり、パールカン自身が 独立した LDL 受容体であることが示された $(48)$ 。糖尿病患者 や糖尿病マウスの腎および他の器官においてパールカンの減 少が観察され、このことがリポタンパク質のクリアランスの 低下を引き起こし、高コレステロール血症、高血糖の発症に 関与していると考えられている $(49,50 、 51) 。$

パールカンはアポ $\mathrm{E}$ 欠損マウスや LDL受容体欠損マウス の動脈硬化肥厚内膜に観察され、動脈硬化の初期病変におい てはリポタンパク質の保持に関与している可能性がある (52) パールカンはヒト以外の動物の码状硬化の進行期の病変部侻 に強く沈着し、その関与が示唆されている(53) しかし、動脈 壁に存在するパールカンの意義はまだ正確にわかっていない アポEと LDL 受容体のノックアウトマウスにパールカンをへ テロで欠損させた場合の䐖状硬化症の変化について調べたを ころ、12 週間同じ食事をさせた後、パールカンがへテロで久 損したアポEと LDL 受容体のノックアウトマウスでは、バー ルカンを欠損しないアポEと LDL 受容体のノックアウトマウ 
mice with a heterozygous deletion had less atherosclerosis, but this difference was not significant at 24 weeks (54). These results suggest that the deficiency of perlecan causes less atherosclerosis in early lesions.

\section{G. Conclusion}

Perlecan is essential for the development of cartilage and myocardium and neural tube closure. It also plays important roles in various functions in adult tissues. The GAG chains of domain I of perlecan are dispensable in development but they may be important in adult tissue functions and remodeling. Recent studies with human genetic disorders associated with the perlecan gene demonstrate that perlecan is indeed a multifunctional proteoglycan. However, the mechanisms of the functions of perlecan in development and diseases remain to be elucidated.
スに比べて、籿状硬化症の初期変化が少なかった(54)。しかし、 24 週後では大きな変化がなかった。この結果から、バールカ ンが欠損すると初期には粥状硬化症が起こりにくい可能性が 示された。

\section{G. 結 語}

パーカンは、軟骨や心血管系の発生や、神経管の閉鎖な どにおいて必須であるが、成体における他の組織の機能にも 重要な㗢きを有している。パールカンのドメインIに付着する GAG 鎖は発生には重要ではないようであるが、成体器官の機 能や組織の再構築においては重要かもしれない。近年のバー ルカン遺伝子欠損疾患の解析からも、バールカンの多機能性 が示されつつあり、さらに発生や疾患におけるパールカン機 能の解明が望まれている。

\section{References}

1. Bernfield, M. et al. (1999) Annu. Rev. Biochem. 68, 729-777

2. Iozzo, R. V. (2001) J. Clin. Invest. 108, 165-167

3. Lin, X. (2004) Development 131, 6009-6021

4. Nakato, H., and Kimata, K. (2002) Biochim. Biophys. Acta. 1573, 312-318

5. Murdoch, A. D., Liu, B., Schwarting, R., Tuan, R. S., and Iozzo, R. V. (1994) J. Histochem. Cytochem. 42, 239-249

6. Noonan, D. M. et al. (1988) J. Biol. Chem. 263, 16379-16387

7. Noonan, D. M. et al. (1991) J. Biol. Chem. 266, 22939-22947

8. Jiang, X., and Couchman, J. R. (2003) J. Histochem. Cytochem. 51, 1393-1410

9. Arikawa-Hirasawa, E., Watanabe, H., Takami, H., Hassell, J. R., and Yamada, Y. (1999) Nat. Genet. 23, 354-358

10. Costell, M. et al. (1999) J. Cell Biol. 147, 1109-1122

11. Nicole, S. et al. (2000) Nature. Genetics. 26, 480-483

12. Arikawa-Hirasawa, E. et al. (2002) Am. J. Hum. Genet. 70, 1368-1375

13. Dolan, M., Horchar, T., Rigatti, B., and Hassell, J. R. (1997) J. Biol. Chem. 272, 4316-4322

14. Brown, J. C., Sasaki, T., Gohring, W., Yamada, Y., and Timpl, R. (1997) Eur. J. Biochem. 250, 39-46

15. Friedrich, M. V., Schneider, M., Timpl, R., and Baumgartner, S. (2000) Eur. J. Biochem. 267, 3149-3159

16. Tapanadechopone, P., Hassell, J. R., Rigatti, B., and Couchman, J. R. (1999) Biochem. Biophys. Res. Commun. 265, 680-690

17. Iozzo, R. V. (1994) Matrix Biol. 14, 203-208

18. Murdoch, A. D., Dodge, G. R., Cohen, I., Tuan, R. S., and Iozzo, R. V. (1992) J. Biol. Chem. 267, 8544-8557

19. Noonan, D. M., and Hassell, J. R. (1993) Kidney Int. 43, 53-60

20. Rogalski, T. M., Williams, B. D., Mullen, G. P., and Moerman, D. G. (1993) Genes Dev. 7, 1471-1484

21. Moerman, D. G., Hutter, H., Mullen, G. P., and Schnabel, R. (1996) Dev. Biol. 173, 228-242

22. Park, Y. et al. (2003) Dev. Biol. 253, 247-257

23. Rogalski, T. M., Mullen, G. P., Bush, J. A., Gilchrist, E. J., and Moerman, D. G. (2001) Biochem. Soc. Trans. 29, $171-176$

24. Talts, J. F., Andac, Z., Gohring, W., Brancaccio, A., and Timpl, R. (1999) Embo. J. 18, 863-870

25. Kramer, K. L., and Yost, H. J. (2003) Annu. Rev. Genet. 37, 461-484

26. Friedrich, M. V. et al. (1999) J. Mol. Biol. 294, 259-270

27. Hassell, J. R. et al. (1980) Proc. Natl. Acad. Sci. USA 77, 4494-4498

28. Molist, A. et al. (1998) Eur. J. Biochem. 254, 371-377

29. Rossi, M. et al. (2003) Embo. J. 22, 236-245

30. Zhou, Z. et al. (2004) Cancer. Res. 64, 4699-4702

31. Morita, H. et al. (2005) J Am Soc Nephrol 16, 1703-1710

32. Smith, S. E. et al. (1997) Dev. Biol. 184, 38-47

33. Handler, M., Yurchenco, P. D., and Iozzo, R. V. (1997) Dev. Dyn. 210, 130-145

34. Rousseau, F. et al. (1994) Nature 371, 252-254

35. Rousseau, F. et al. (1996) Horm. Res. 45, 108-110

36. Wilcox, W. R. et al. (1998) Am. J. Med. Genet. 78, 274-281

37. Ornitz, D. M. (2001) Regulation of chondrocyte growth and differentiation by fibroblast growth factor receptor 3 . Novartis Found Symp. 232, 63-76; discussion 76-80, 272-282

38. Brodie, S. G., and Deng, C. X. (2003) Pediatr. Pathol. Mol. Med. 22, 87-103

39. Deng, C., Wynshaw-Boris, A., Zhou, F., Kuo, A., and Leder, P. (1996) Cell 84, 911-921

40. Arikawa-Hirasawa, E. et al. (2001) Nat. Genet. 27, 431-434

41. Aleck, K. A. et al. (1987) Am. J. Med. Genet. 27, 295-312 
42. Spranger, J., Hall, B. D., Hane, B., Srivastava, A., and Stevenson, R. E. (2000) Am. J. Med. Genet. 94, 287-295

43. Tesche, F., and Miosge, N. (2004) Osteoarthritis Cartilage 12, 852-862

44. Arikawa-Hirasawa, E., Rossi, S. G., Rotundo, R. L., and Yamada, Y. (2002) Nat. Neurosci. 5, 119-123

45. Sanes, J. R., and Lichtman, J. W. (1999) Annu. Rev. Neurosci. 22, 389-442

46. Steen, M. S., and Froehner, S. C. (2003) Trends. Neurosci. 26, 241-242

47. Rotundo, R. L. (2003) J. Neurocytol. 32, 743-66

48. Fuki, I. V., Iozzo, R. V., and Williams, K. J. (2000) J. Biol. Chem. 275, 25742-25750

49. Ebara, T. et al. (2000) J. Clin. Invest. 105, 1807-1818

50. Conde-Knape, K. (2001) Diabetes Metab. Res. Rev. 17, 412-421

51. Menne, J. et al. (2004) Diabetes 53, 2101-2109

52. Kunjathoor, V. V., Chiu, D. S., O’Brien, K. D., and LeBoeuf, R. C. (2002) Arterioscler. Thromb. Vasc. Biol. 22, $462-468$

53. Evanko, S. P., Raines, E. W., Ross, R., Gold, L. I., and Wight, T. N. (1998) Am. J. Pathol. 152, 533-546

54. Vikramadithyan, R. K. et al. (2004) Atherosclerosis in perlecan heterozygous mice. J. Lipid. Res. 45, 1806-1812

Received on August 30, 2005, accepted on September 29, 2005

\section{Profile of the Author}

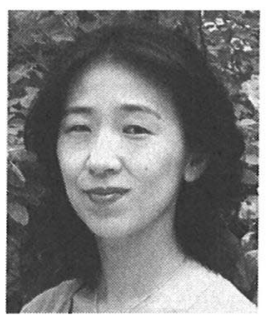

Eri Arikawa-Hirasawa is a neurologist who graduated from Juntendo University School of Medicine. She worked at the National Institute of Dental and Craniofacial Research, National Institute of Health for the past 5 years(1996-2001). She is now a Lecturer at Juntendo University. Her major interest has been in muscle disorders and neural development. She is now focusing on role extracellular matrix in diseases and development. 